\title{
DIGITAL INFLUENCERS AND VLOGGING ADVERTISING: CALLING FOR AWARENESS, GUIDANCE AND ENFORCEMENT
}

Valerie Verdoodt ${ }^{1}$ and Nadia Feci ${ }^{2}$

\section{INTRODUCTION}

Nowadays, people can participate online, create and share their own content in all kinds of applications such as blogs, social media and video-sharing platforms. Children and adolescents are increasingly consuming media content online, where their favourite digital influencers upload videos on a regular basis (e.g. on YouTube). Content creators like vloggers (i.e. video bloggers) have over time become extremely popular amongst the younger audiences and even in some instances gained celebrity status among their thousands of followers. ${ }^{3}$ The influence these people may exert over their loyal followers is significant and brings with it certain responsibilities, especially when commercial interests become involved. The popularity of these digital influencers is already shaping advertising and marketing techniques and vlogging advertising may take many forms, such as online marketing by a brand with vlogger collaboration, an advertorial, a commercial break within a vlog, product placement, the promotion of the vlogger's own merchandise, sponsorship and free items. ${ }^{4}$ These integrated advertising techniques form an important source of revenue for vloggers. ${ }^{5}$ Professional influencer has become just another job and vloggers may be tied to agents and production companies, just like movie actors. ${ }^{6}$

This paper analyses the persuasive tactics used by digital influencers in vlogs targeted towards children, in light of the existing regulatory framework for commercial communication. More specifically, it addresses children's fundamental rights in this

\footnotetext{
1 Valerie Verdoodt is as senior researcher attached to the Centre for IT and IP Law and KU Leuven. This paper was inspired by her $\mathrm{PhD}$ research entitled "Children's rights and advertising literacy in the digital era: Towards an empowering regulatory framework for commercial communication".

${ }^{2}$ Nadia Feci is as legal researcher attached to the Centre for IT and IP Law and KU Leuven. This paper received input from her master thesis entitled "The rise of the vloggers: integrated advertising and the current regulatory framework".

${ }^{3}$ For instance, Industry research has shown that $59 \%$ of 13 year-olds follows YouTubers on social media versus only 32\% following television and movie stars. 'Acumen Report: Youth Video Diet' (Defy Media) $<$ http://defymedia.com/wp-content/uploads/2017/11/Acumen_DL_booklet_16_12_04.pdf> accessed 29 November 2017.

${ }^{4}$ This list is not exhaustive and stems from the CAP Guidelines, a UK self-regulatory initiative, see infra. J. Ward, 'CAP Guidance on Vlogging Advertising' [2016] Entertainment Law 49.

${ }^{5}$ Vloggers may be rewarded inter alia on the basis of 'pay per acquisition or download' (i.e. earn rewards whenever a viewer purchases a product or service via the link within the vlog); product compensation; pay per post or a system of flat rate pricing; pay per click. Commercial communications organised by YouTube itself (pre-, mid- and end-rolls during videos, banners etc.) outside the scope of this paper.

${ }^{6}$ In the US, YouTubers even have united in the Internet Creators Guild, which provides YouTubers with support to help them develop a rigorous business sense and avoid exploitation. C. Stokel-Walker, 'Vloggers Unite: Youtubers Are Getting Organized after a Decade of Exploitation' Newsweek (8 October 2016) $<$ http://www.newsweek.com/vloggers-youtube-organized-decade-exploitation-507592> accessed 30 October 2018.
} 
specific context, it clarifies the scope of the relevant EU Directives (i.e. the Audiovisual Media Services Directive ("AVMS Directive"), the e-Commerce Directive and the Unfair Commercial Practices Directive ("UCP Directive")) and touches briefly upon an interesting case of the Belgian self-regulatory body for the advertising industry.

\section{PERSUASIVE TACTICS AND CHILDREN'S FUNDAMENTAL RIGHTS}

Digital influencers use specific persuasive tactics in their audiovisual content, which may significantly impact children's rights. Viewers or followers seek guidance from these media personalities, see them as friends or imagine that they are part of a programme's social world.7 According to PERSE and RUBIN, viewers "feel that they know and understand the influencer in the same intimate way they know and understand flesh and blood friends". ${ }^{8}$ Followers will turn to influencers for advice and regard them as a trusted source of information. Children in particular perceive digital influencers as more relatable than traditional celebrities and they can identify themselves more with the former. ${ }^{9}$ As a result, digital influencers have become an important intermediary between advertisers and consumer-followers. The two-way communication between the media personality and the fans is facilitated by social media, which often contains product reviews and information. ${ }^{10}$

Research has shown that user-generated content generally has a significant influence on consumers' brand perspective, brand choices ${ }^{11}$ and new consumer acquisition ${ }^{12}$. Vlogging advertising allows targeted exposure to the right consumers and repeated exposure to a vlogger can elicit enhanced feelings of connectedness with the advertised brands. As humans are social creatures, they tend to copy behaviours and beliefs of people they like. ${ }^{13}$ In this regard, LEE and WATKINS refer to social comparison theory ${ }^{14}$, which entails that as consumer-followers view themselves as sharing similar opinions and preferences as digital influencers, a positive review of a brand from their preferred vlogger may lead to a positive review from the consumer. ${ }^{15}$

Considering the often hidden nature of vlogging advertising and the highly entertaining videos, digital influencers can have a direct impact on children's consumption behaviour

\footnotetext{
7 J. E. Lee and B. Watkins, 'YouTube Vloggers' Influence on Consumer Luxury Brand Perceptions and Intentions' (2016) 69 Journal of Business Research 5753.

8 E. M. Perse and R. B. Rubin, 'Attribution in Social and Parasocial Relationships' (1989) 16 Communication Research 59.

9 'Acumen Report: Youth Video Diet' (n 3).

${ }^{10}$ Lee and Watkins (n 7).

11 T. W. Gruen, T. Osmonbekov and A. J. Czaplewski, 'EWOM: The Impact of Customer-to-Customer Online Know-How Exchange on Customer Value and Loyalty' (2006) 59 Journal of Business Research 449.

12 M. Trusov, R. E. Bucklin and K. Pauwels, 'Effects of Word-of-Mouth versus Traditional Marketing: Findings from an Internet Social Networking Site' (2009) 73 Journal of marketing 90.

${ }^{13}$ A. R. Bentley, Mark Earls and Michael O'brien J, I'll Have What She's Having - Mapping Social Behavior <https://mitpress.mit.edu/books/ill-have-what-shes-having> accessed 29 November 2017.

14 This theory was developed in the 1950s by personality theorists, including N. E. Miller and J. Dollard, Social Learning and Imitation (Yale University Press 1941); A. Bandura and R. H. Walters, Social Learning and Personality Development (Holt, Rinehart and Winston 1963).

${ }^{15}$ Lee and Watkins (n 7).
} 
without them being aware of the commercial nature of the communications. ${ }^{16}$ In this regard, vlogging advertising may have a significant impact on children's right to development, freedom of thought and the right to protection from economic exploitation under the United Nations Convention on the Rights of the Child. ${ }^{17}$ This of course may need to be offset with the freedom of expression of the digital influencers themselves. ${ }^{18}$ Furthermore, as vlogging forms an important part of popular youth culture, it also enables children to participate online and exercise their rights to freedom of expression and culture.

\section{DIGITAL INFLUENCERS AND THE CURRENT REGULATORY FRAMEWORK}

A previous mapping of the legal and self- and co-regulatory framework for commercial communication identified important requirements that are also applicable in the online environment, the key requirement being the identification principle (i.e. commercial communication has to be identifiable as such). ${ }^{19}$ In the context of vlogging advertising, three important directives exist at the EU level: the AVMS Directive, the e-Commerce Directive and the UCP Directive. For the purpose of this paper, it is important to analyse the scope and requirements of these instruments. Furthermore, the responsibilities of the different parties involved for the implementation of these requirements in practice need to be clarified. Finally, this paper touches upon the specific guidelines for vloggers in selfregulation.

\subsection{Audiovisual or commercial communication?}

\subsubsection{Untangling the vlogging advertising chain}

A first question that needs to be answered is whether vlogging as a service would fall under the definition of an audiovisual media service (AVMS Directive) or an information society service (e-Commerce Directive) and subsequently whether vlogging advertising could fall under the notion 'audiovisual commercial communication' (AVMS Directive) or rather under the more general e-Commerce notion of 'commercial communication' (eCommerce Directive). ${ }^{20}$ The distinction is significant considering the more stringent requirements for audiovisual commercial communication. As the vlogging advertising

\footnotetext{
16 For instance, a risk assessment of new advertising formats conducted in the frame of the AdLit Project showed that the advertising literacy level for brand integration, advertiser funded programs, social media advertising and advergaming is rather low, posing a greater risk for children and teenagers. See I. Vanwesenbeeck and others, 'Minors' Advertising Literacy in Relation to New Advertising Formats Identification and Assessment of the Risks' (2016) <www.adlit.be> accessed 16 November 2017.

17 V. Verdoodt, 'Children's Rights and Advertising Literacy in the Digital Era: Towards an Empowering Regulatory Framework for Commercial Communication’ (KU Leuven, UGent 2018).

18 For examples of cases where commercial speech is balanced against other interests see Casado Coca $v$ Spain [1994] ECtHR Series A., No. 285; Barthold v Germany [1985] ECtHR App No 8734/79.

19 V. Verdoodt, E. Lievens and L. Hellemans, 'Mapping and Analysis of the Current Legal Framework on Commercial Communication Aimed at Minors. A Report in the Framework of the AdLit Research Project.' (2015) <www.adlit.be> accessed 20 November 2017; V. Verdoodt, I. Lambrecht and E. Lievens, 'Mapping and Analysis of the Current Self- and Co-Regulatory Framework on Commercial Communication Aimed at Minors. A Report in the Framework of the AdLit SBO Project.' <www.adlit.be> accessed 20 November 2017. 20 This is a similar evaluation like the one in the context of advergames, supra.
} 
chain may consist of several parties, it needs to be clarified who is responsible for the implementation of the requirements in practice.

First of all, it is argued that vlogging may qualify as an information society service under the e-Commerce Directive. These services can be "any service normally provided for remuneration, at a distance, by electronic means and at the individual request of a recipient of services." ${ }^{11}$ The service provided here entails the provision of videos and making them available to the public on video-sharing platforms like YouTube. In return, the influencer receives a reward, be it in the form of a financial remuneration, free products or services, promotion for their own products, etc. As the videos are uploaded on digital platforms, the requirement of 'by electronic means' is also fulfilled. Lastly, the video is shown at the individual request of the viewer, therefore fulfilling all requirements. Accordingly, the eCommerce Directive requires digital influencers engaging in vlogging advertising to comply with several information requirements as well as with the identification principle. $^{22}$

The more difficult question, however, is whether vlogging and vlogging advertising could fall within the scope of the AVMS Directive. The central definition determining the scope of the AVMS Directive is the notion of an audiovisual media service. ${ }^{23}$ From this definition, certain elements can be extracted that need to be present for vlogging advertising to fall within the scope of the Directive.

First, the Directive comprises economic activities, an element that can only be found with the more professional digital influencers, as the rewards they receive for vlogging advertising may be regarded as remuneration. ${ }^{24}$ For instance, if digital influencers promote products or services in the style of a review for their followers, a clear indicator of a commercial intent can be found if the video is made in return for financial compensation or if there are other financial ties between the vlogger and the advertiser (product owner). ${ }^{25}$ As mentioned, vloggers may also be tied to agents who receive a part of the advertising revenue generated by the vlogger. Conversely, the Directive does not apply to activities that are primarily non-economic, including inter alia the provision of user-generated content for the sole purpose of sharing and exchanging within communities of interest or to private websites or blogs. ${ }^{26}$ Thus, this first element will

\footnotetext{
21 Recital 17 e-Commerce Directive.

${ }^{22}$ Article 6 of the e-Commerce Directive requires digital influencers to disclose their identity and in case they launch any promotional competition or game the conditions for participation shall be easily accessible and be presented clearly and unambiguously.

23 Article 1(1)(h) AVMS Directive.

${ }^{24}$ For instance the YouTube star PewDiePie, who started with uploading silly (and often crude) snippets of himself playing videogames, now has 50 million subscribers and earns approximately \$15 million a year of commercial collaborations. Madeline Berg, 'The Highest-Paid YouTube Stars 2016: PewDiePie Remains No. 1 With \$15 Million' (Forbes) <https://www.forbes.com/sites/maddieberg/2016/12/05/the-highest-paidyoutube-stars-2016-pewdiepie-remains-no-1-with-15-million/> accessed 15 December 2017.

25 Verdoodt, Lievens and Hellemans (n 19).

${ }^{26}$ R. Chavannes and O. Castendyk, 'Directive 2007/65/EC “Audiovisual Media Services Directive”' in 0. Castendyk, E. Dommering and A. Scheuer (eds), European Media Law (Kluwer Law International 2008).
} 
depend on the intent of the digital influencer and/or the platform provider and the commercial influence on or interference with the content of the vlogs.

As a second requirement, the commercial communication needs to accompany or be included in a programme ${ }^{27}$ established by a media service provider. VALCKE and LIEVENS clarify that the notion of a programme needs to be interpreted in a dynamic way, taking into account the developments in television broadcasting. ${ }^{28}$ In this regard, in the most recent revision of the AVMS Directive, the definition of a programme was broadened to include videos irrespective of their length. This change reflects the transformed viewing habits of children and adolescents, who increasingly consume audiovisual content via tablets and smartphones. ${ }^{29}$ Children and adolescents arguably may find certain vlogs or series of vlogs similar to traditional television broadcasting, depending on the format ${ }^{30}$ and content of the videos (e.g. episodes in the life of a digital influencer). The professionalism of some of these digital influencers and their 'channels', the regular upload of edited vlogs (e.g. daily, weekly) and the fact that the channels are accessible on the same screen as traditional broadcasts may contribute to such a finding. The Directive requires that the programme should be aimed to inform, entertain or educate the general public and the service should be provided by electronic communications networks. With regard to vlogging, these elements may be present, as the videos of digital influencers may have an entertaining, informative or educative purpose ${ }^{31}$ and viewers or followers can access the content online via the video-sharing platform.

The requirement of 'accompanying or being included in a programme' also links to another element, namely editorial responsibility, which requires the exercise of effective control over both the selection and the organisation of the programmes. ${ }^{32}$ This entails that a professional media service provider is responsible for the editorial design and final compilation of a programme for broadcasting in accordance with a fixed programme

\footnotetext{
${ }^{27}$ Article 1 (b) AVMS Directive. Excluded are those services which are audio-only and not sufficiently television-like services such as radio, electronic versions of newspapers and magazines, blogs.

${ }^{28}$ P. Valcke and E. Lievens, 'Rethinking European Broadcasting Regulation: Unraveling Europe's Policy for the Digital Media Landscape: Critical Analysis of the Audiovisual Media Services Directive' (VUB Press 2009).

${ }^{29}$ For instance, research by Ofcom, the UK media regulator, showed that children are watching less broadcast television as they turn to online activities and services such as YouTube. Jasper Jackson, 'Children Spending Less Time in Front of the TV as They Turn to Online Media' The Guardian (6 August 2015) <http://www.theguardian.com/media/2015/aug/06/children-spending-less-time-in-front-of-tv-ofcom> accessed 7 December 2017.

${ }^{30}$ In this regard, the media regulator of the French-speaking community in Belgium underlines that more and more high quality short forms of content are appearing on audiovisualplatforms which can have a high impact on the public opinion and they are competing with the same audience as TV broadcasts. J. Dheur, 'Belgian CSA Conference - The Platform Is the Message' (2016) <http://www.csa.be/system/documents_files/2591/original/CI_20160310_The\%20Platform\%20is\%20t he\%20Message_report.pdf?1458160565> accessed 11 December 2017.

${ }^{31}$ Accordingly, the case of digital influencers differs from the Peugeot Deutschland case, in which the CJEU decided that a YouTube channel of Peugeot containing short promotional videos for new passenger car models did not have as its principal purpose the provision of programmes in order to inform, entertain or educate the general public and thus excluding it from the scope of the AVMS Directive. Peugeot Deutschland GmbH v Deutsche Umwelthilfe eV [2018] CJEU C-132/17 [28].

${ }^{32}$ Article 1 (1) (c) AVMS Directive.
} 
schedule or for viewing on-demand for a catalogue. ${ }^{33}$ In other words, the AVMS Directive provides regulatory standards for professionally created mass media content. ${ }^{34}$ Applying this criterion in a vlogging context is not straightforward considering many new players have entered the value chain. First, SCHOEFS underlines that video-sharing platforms like YouTube play a crucial role in providing access to users to both user-generated content and edited professional content. YouTube hosts a massive amount of content, which it organises into different categories depending on the topic of the uploaded video. ${ }^{35}$ While it seemed well established that the AVMS Directive - prior to its most recent review - did not apply to amateur user-generated content ${ }^{36}$, the same could not be said for professional content which has been provided and/or edited by the platform provider or a professional third party provider before the upload ${ }^{37}$. Indeed, several Member States accepted that such professional content and channels did fall within the scope of the AVMS Directive and, as such, assigned the responsibility wherever the editorial power rests. ${ }^{38}$ Second, the segregation of content produced by professional and amateur vloggers forms a major borderline case. On the one hand, the content that some of these professional vloggers create could arguably be considered 'television-like' (e.g. reality shows with episodes airing every week), especially for children and adolescents who watch less traditional broadcasts. ${ }^{39}$ Furthermore, vloggers' capacity to influence social trends, the ubiquity of integrated commercial messages and the significant financial rewards they gain in return call for more stringent requirements or even restrictions. On the other hand, making such a distinction is extremely complicated and would require a case-bycase analysis taking into account all relevant characteristics and evidence. ${ }^{40}$ Important to note is that the revised AVMS Directive provides some clarity on the matter, with recital 3 of the final text stating that:

\footnotetext{
33 Verdoodt, Lievens and Hellemans (n 19).

34 W. Closs, S. Nikoltchev and European Audiovisual Observatory (eds), The Regulation of On-Demand Audiovisual Services: Chaos or Coherence? (European Audiovisual Observatory: Council of Europe 2011).

35 R. Schoefs, 'Connected TV: Editorial Responsibility in a Converged Media Environment' (2014) 5 Droit des médias - Mediarecht 346.

36 Chavannes and Castendyk (n 26).

37 Schoefs (n 35); D. Clifford and V. Verdoodt, 'Integrative Advertising: The Marketing'dark Side'or Merely the Emperor's New Clothes?' (2017) 8 European Journal of Law and Technology $<$ http://ejlt.org/article/view/547> accessed 8 August 2017.

38 Schoefs (n 35). Austria, Belgium, Finland, Italy, The Netherlands and Slovenia. For example, the author mentions BBC's Top Gear YouTube channel. Video sharing platform providers will be directly responsible for their own placement of commercial communications on the platform (e.g. banners, personalised advertising). Hence, the platform itself will be responsible for satisfying the identification requirements in these situations. However, it is important to note that the platform provider will only be editorially responsible for its own content. This means that the provider of the third party content on that platform should comply with the AVMS Directive if he in his turn can be held editorially responsible for his content. ${ }^{39}$ For instance research by Ofcom showed that are supplementing their TV viewing by turning to sites such as YouTube, Vimeo and Vine, as well as watching clips posted on Facebook or Twitter and news websites. Ofcom, 'Children's Content Review : Update Assessing the Current Provision of Children's Programmes on TV and Online' (2018) 9 <https://www.ofcom.org.uk/_data/assets/pdf_file/0023/116519/childrenscontent-review-update.pdf $>$ accessed 2 August 2018.

40 Criteria to take into account could include inter alia the type of vlogs provided, the amount of videos uploaded and the consistency of uploads, the editorial work performed, the financial rewards gained by the influencer.
} 
"channels or any other audiovisual services under the editorial responsibility of a provider may constitute audiovisual media services in themselves, even if they are offered in the framework of a video-sharing platform which is characterised by the absence of editorial responsibility. In such cases, it will be up to the providers with editorial responsibility to abide by the provisions of this Directive." 41

In other words, user-generated content is no longer excluded from the scope of the AVMS Directive. Recital 3 implicitly recognises the possibility of user-generated content being subject to the Directive.

Attributing responsibility to platform providers in the context of digital influencers would alter the generally accepted interpretation of 'selection' as a way to exercise control. ${ }^{42}$ Several European media regulators found that in the case of video-sharing platforms like YouTube or DailyMotion, there is neither any selection of videos as everyone can upload them, nor any organisation of the videos in function of their content by the platform provider. ${ }^{43}$ This is supported by the fact that these providers often remain outside the specific vlogging advertising revenue chain as they merely facilitate the delivery of the videos to the influencer's audience and usually generate an income through other forms of digital advertising (e.g. banners, personalised pre-rolls) ${ }^{44}$ accompanying the influencer's videos. ${ }^{45}$ However, if the platform provider is the one who engages the services of such professional influencers, the interpretation of editorial responsibility, selection and effective control becomes even more complex. ${ }^{46}$ Furthermore, the increased use of automated means of selection and organisation (e.g. algorithmic recommender systems ${ }^{47}$ ) potentially decreases the role of the digital influencers uploading videos and strengthens that of the platform provider, thereby having a de facto influence on viewers' choice. ${ }^{48}$ For these reasons, the Belgian ${ }^{49}$ and German media regulators called for a special

\footnotetext{
${ }^{41}$ Recital 3 of the Final Compromise Text, see Council of the European Union, 'Proposal for a Directive of the European Parliament and of the Council Amending Directive 2010/13/EU on the Coordination of Certain Provisions Laid down by Law, Regulation or Administrative Action in Member States Concerning the Provision of Audiovisual Media Services (Audiovisual Media Services Directive) in View of Changing Market Realities - Analysis of the Final Compromise Text with a View to Agreement' (2018) <http://data.consilium.europa.eu/doc/document/ST-9817-2018-INIT/en/pdf> accessed 25 July 2018.

${ }^{42}$ Clifford and Verdoodt (n 37).

${ }^{43}$ Schoefs (n 35).

${ }^{44}$ L. Hellemans, E. Lievens and P. Valcke, 'Playing Hide-and-Seek? A Legal Perspective on the Complex Distinction between Commercial and Editorial Content in Hybrid Advertising Formats' (2015) 17 info 19.

${ }_{45}$ Clifford and Verdoodt (n 37); Schoefs (n 35).

${ }^{46}$ YouTube recently launched a premium subscription-only version.

47 YouTube's recommendations system helps users discover personalised content from an ever-growing corpus of videos. It takes as input inter alia user's watch history, implicit feedback of video watches by users and explicit feedback such as a thumbs up or a thumbs down and through filtering selects videos in the range of hundreds. P. Covington, J. Adams and E. Sargin, 'Deep Neural Networks for YouTube Recommendations' (ACM Press 2016) <http://dl.acm.org/citation.cfm?doid=2959100.2959190> accessed 7 December 2017.

${ }^{48}$ Schoefs (n 36); Clifford and Verdoodt (n 38).

49 More specifically, the media regulator of the French-speaking Community, Conseil Superieur de l'Audiovisuel <http://www.csa.be/>.
} 
category under EU law for large audiovisual platforms that is subject to the (or some of the core $^{50}$ ) provisions of the AVMS Directive. ${ }^{51}$

\subsubsection{Broadening the audiovisual playground to include new players}

In its 2016 REFIT evaluation of the AVMS Directive, the European Commission recognises the lack of a level-playing field for traditional and new audiovisual media providers, as well as the lack of consumer protection in relation to the latter. ${ }^{52}$ Furthermore, considering that these new digital providers increasingly offer audiovisual content online, and research has shown that video viewing is one of the earliest internet activities preferred by young children, it made sense to include them in the scope of the AVMS Directive, especially in relation to the protection of minors. The revised AVMS Directive, therefore, explicitly refers to a new category of 'video-sharing platform services' ("VSPs"), which will be subject to specific rules. To fall within the scope of the definition, several cumulative conditions need to be fulfilled ${ }^{53}$ :

$\checkmark$ First, it needs to be a service normally provided for remuneration, which entails an economic activity, and its principal purpose needs to be of interest to the general public. As mentioned, this may also include services financed by advertising like a vlogger's YouTube channel. ${ }^{54}$

$\checkmark$ Second, the platform service must consist of the provision of programmes or usergenerated videos to the general public, for which the service provider does not have editorial responsibility. However, it is up to the national legislator to determine the exact meaning of the concept of editorial responsibility. 55

$\checkmark$ Third, the service provider must determine the organisation of the stored content. This includes the organisation by automatic means, such as displaying, tagging and sequencing. Video-sharing platforms like YouTube and Dailymotion (or at the very least specific parts or sections of these platforms) will most likely fulfil the conditions.

$\checkmark$ Fourth, the principal purpose of the service or a dissociable section thereof or an essential functionality of the service must be devoted to providing programmes and

\footnotetext{
${ }^{50}$ SCHOEFs for instance refers to the obligations in relation to commercial communication and the protection of minors under the AVMS Directive. Schoefs (n 35).

${ }^{51}$ Dheur (n 30).

52 DG CONNECT, 'REFIT Evaluation and Impact Assessment of the EU Audiovisual Media Services Directive 2010/13/EU (AVMSD)' <http://ec.europa.eu/smartregulation/roadmaps/docs/2015_cnect_006_cwp_review_avmsd_iia_en.pdf> accessed 6 December 2017. ${ }^{53}$ Art. 1 (aa) Compromise Text AVMS Directive.

${ }^{54}$ Conversely, more private websites where video-sharing takes place within certain communities or groups (e.g. a website of the dancing school for children where videos are uploaded exclusively for parents).

55 The same margin of appreciation has led in the past to different interpretations. For instance, HERMANNS and MATZNELLER are of the opinion that the extensive cataloguing and composing of programmes would fall under editorial responsibility and the media regulator of the French-speaking Community of Belgium ruled that the sole possibility of exercising control over the content of programmes would be sufficient. Olivier Hermanns, Peter Matzneller and Susanne Nikoltchev, 'The Regulation of On-Demand Audiovisual Services : Chaos or Coherence?' [2011] IRIS Special: The regulation of on-demand audiovisual services: chaos or coherence?
} 
user-generated videos to the general public, in order to inform, entertain or educate.

$\checkmark$ Finally, the service needs to be made available through electronic communications networks.

As is clear for these cumulative criteria, the revised Directive aims to overcome the difficulties described above associated with the interpretation of editorial responsibility. .5

An interesting question that arises is whether or not social media platforms such as Facebook are included in the VSP definition. The revised Directive strongly emphasises the role of social media services in young people's lives, recognising that they "have a considerable impact in that they facilitate the possibility for users to shape and influence the opinions of other users" ${ }^{57}$ Furthermore, such services also compete for the same audiences and the revenues as audiovisual media services and, therefore, are included in the scope of the Directive. However, social media services are only covered by the Directive insofar as they fall under the definition of a VSP. The Directive clarifies that social media services are included when the provision of programmes or user-generated videos could be considered an essential functionality of that service, meaning 'not merely ancillary or a minor part of its activities'. Therefore, it needs to be assessed to what extent social media services revolve around providing user-generated audiovisual content. ${ }^{58}$ This assessment will need to be decided on a case-by-case basis, and may change over time when these services evolve. ${ }^{59}$ It is up to the European Commission to provide guidelines on the practical application of this criterion of essential functionality.

The actual impact of the introduction of VSPs into the AVMS Directive on digital influencers and vlogging advertising depends on whether or not the provisions on commercial communication are applicable to such platforms. In this regard, article 28a of the revised Directive requires VSP providers to take appropriate measures to protect:

(a) minors from programmes, user-generated videos and audiovisual commercial communications which may impair their physical, mental or moral development in accordance with Article 6a(1);

(b) the general public from programmes, user-generated videos and audiovisual commercial communications containing incitement to violence or hatred directed

\footnotetext{
56 The second and third requirement aim to specifically cater for these problems and the increased usage of automated means of selection and organisation by platforms. Clifford and Verdoodt (n 38).

${ }^{57}$ Recital 3a of the Final Compromise Text.

58 I. Lambrecht, V. Verdoodt and J. Bellon, 'Platforms and Commercial Communications Aimed at Children: A Playground under Legislative Reform?' [2018] International Review of Law, Computers and Technology. 59 K. Ehle, 'Digital Single Market Update: The European Commission's Proposal to Revise the Audiovisual Media Services Directive' (Lexology) <https://www.lexology.com/library/detail.aspx?g=dc9d66d9-f9164f0b-b0cc-f3b6e2f45de4> accessed 15 December 2017. Facebook, for instance, has been increasingly investing in audiovisual content (e.g. Facebook Watch application). J. Costine, 'Facebook Launches Watch $\mathrm{Tab}$ of Original Video Shows' (Techcrunch, 9 August 2017) <https://techcrunch.com/2017/08/09/facebook-watch/> accessed 15 December 2017.
} 
against a group of persons or a member of a group based on any of the grounds referred to in Article 21 of the Charter of the Fundamental Rights of the European Union;

(ba) the general public from programmes, user-generated videos and audiovisual commercial communications containing content the dissemination of which constitutes an activity which is a criminal offence under Union law, namely public provocation to commit a terrorist offence within the meaning of Article 5 of Directive (EU) 2017/541, offences concerning child pornography within the meaning of Article 5(4) of Directive 2011/93/EU and offences concerning racism and xenophobia within the meaning of Article 1 of Council Framework Decision 2008/913/JHA on combating certain forms and expressions of racism and xenophobia by means of criminal law. (Emphasis added)

Thus, VSP providers are required to take measures to protect minors from harmful audiovisual commercial communications and the general public from audiovisual commercial communications containing hate speech or illegal content. In addition, VSP providers also have to ensure compliance with article 9(1) of the Directive, which requires inter alia that audiovisual commercial communications should be recognisable as such (i.e. the identification principle) and should not directly exhort minors to buy or hire a product or service by exploiting their inexperience. ${ }^{60}$ However, this requirement only applies to those audiovisual commercial communications that are marketed, sold or arranged by the VSP provider. In contrast, for those that are not (for instance vlogging advertising arranged by a digital influencer), the revised Directive recognises the limited control exercised by VSP providers over such commercials and requires that VSP providers take appropriate measures. In order to determine what measures are appropriate, VSP providers have to take into account the

"nature of the content in question, the harm it may cause, the characteristics of the category of persons to be protected as well as the rights and legitimate interests at stake, including those of the video-sharing platform providers and the users having created and/or uploaded the content as well as the public interest." 61

Additionally, the measures have to be practicable and proportionate, in light of the actual size of the VSP service and the nature thereof. Important to note is that the revised Directive explicitly states that such measures may not lead to any type of ex-ante control or a filtering of uploaded content, as this would not comply with article 15 of the e-Commerce Directive. ${ }^{62}$ The revised Directive also provides a list of potential measures, including inter alia adding the identification requirement in the VSPs terms and conditions; installing flagging, age

\footnotetext{
${ }^{60}$ Article 28 (1a) of the Final Compromise Text.

61 Article 28 (2) of the Final Compromise Text.

62 Article 15 of the e-Commerce Directive states that "Member States shall not impose a general obligation on providers, when providing the services covered by Articles 12, 13 and 14, to monitor the information which they transmit or store, nor a general obligation actively to seek facts or circumstances indicating illegal activity."
} 
verification, parental control and rating mechanisms; and media literacy measures. ${ }^{63}$ For the implementation of these measures, Member States are required to encourage the use of co-regulation.

\subsection{The safety net of the Unfair Commercial Practices Directive}

The UCP Directive is a horizontal Directive, containing rules for commercial communications regardless of the form or delivery used. It applies to unfair business-toconsumer practices, including commercial communications directly connected with the promotion, sale or supply of a product to consumers. Because of its general scope, it will be applicable to many commercial practices that are also regulated by other general or sector-specific EU legislation. ${ }^{64}$ In this regard, the more specific requirements laid down under other EU legislation usually add to the general requirements of the UCP Directive, thus offering complementary protection (unless the aspect is specifically regulated by the sector-specific rules). 65

\subsubsection{Unfair commercial practices by digital influencers and third-party traders}

Video-sharing platforms like YouTube have become platforms for commercial communication, in the form of advertising, product placement, reviews, etc. In this regard, digital influencers promoting brands, products or services of a company (or their own) could qualify as traders under the UCP Directive. We have seen that a trader is "anyone (including legal persons) who is acting for the purposes relating to his trade, business, craft or profession, and anyone acting on behalf of another trader". ${ }^{66}$ This means that both the brand or company that wants to promote their goods or services and the digital influencer that is hired to engage in the promotion could qualify as traders under the UCP Directive.

In the context of social media and VSPs, the European Commission (2016) has warned for increased risks to hidden and misleading advertising, as commercial elements are often mixed with social and cultural user-generated content. ${ }^{67}$ Moreover, consumers experience these platforms just as services for exchanging information or communicating with other consumers. As such, they are often unaware of traders employing these platforms for advertising and marketing purposes. Regulatory authorities of several Members found the practice of companies paying bloggers to promote and advertise their products on a blog aimed at teenagers without disclosing the commercial nature of the

\footnotetext{
${ }^{63}$ Article 28 (2) of the Final Compromise Text. In relation to the age verification and parental control mechanisms, the Directive prohibits that any personal data of minors collected in this context is used or resold for commercial purposes (e.g. behavioural advertising, direct marketing).

64 European Commission, 'Commission Staff Working Document - Guidance on the Implementation/Application of Directive 2005/29/EC on Unfair Commercial Practices, SWD(2016) 163 Final.' (2016) <http://ec.europa.eu/justice/consumer-marketing/files/ucp_guidance_en.pdf> accessed 9 October 2017.

${ }^{65}$ In this regard, article 3 (4) of the UCP Directive clarifies that "in case of conflict between the provisions of this Directive and other Community rules regulating specific aspects of unfair commercial practices, the latter shall prevail and apply to those specific aspects."

${ }^{66}$ Article 2(b) UCP Directive.

${ }^{67}$ European Commission (n 64).
} 
blogs to be a hidden commercial practice. ${ }^{68}$ By analogy, the same reasoning could be applied in the context of vlogging. Other examples of commercial practices by third party traders (e.g. brands) and/or digital influencers include:

$\checkmark$ A third party trader encourages users to share marketing material with other users by offering price reductions on its marketed products as a reward.

$\checkmark$ A blogger is given a free vacation by a tour operator in exchange for posting positive reviews on the vacation and the tour operator.

$\checkmark$ A celebrity (music, sports) is given an endorsement deal in exchange for posting pictures of bought products such as sneakers. ${ }^{69}$

The UCP Directive has tackled the problem of hidden traders, by explicitly forbidding in all circumstances the practices of

"falsely claiming or creating the impression that the trader is not acting for purposes relating to his trade, business, craft or profession, or falsely representing oneself as a consumer". (Emphasis added)

For example, traders are not allowed to post fake reviews in the name of consumers or by using e-reputation agencies. Furthermore, digital influencers and traders should refrain from " using editorial content in the media to promote a product where a trader has paid for the promotion without making that clear in the content or by images or sounds clearly identifiable by the consumer (advertorial)". Thus, the UCP Directive clearly requires that digital influencers disclose the commercial nature of their vlogs to their consumerfollowers. Important to note is that the Directive does not provide further details on what such a disclosure should look like. With regard to advertorials, this could be either 'by images or sounds', and it has to be 'clearly identifiable'.

Also relevant for digital influencers is article 6 of the UCP Directive which protects consumers against misleading commercial practices involving the use of systems such as 'likes'. The EC clarifies that by presenting fake 'likes' to consumers, a digital influencer or third party trader may mislead consumers about its own reputation or the reputation of its products or services. In turn, this could potentially influence consumers' purchasing behaviour, causing them to take transactional decisions they would not have taken otherwise. ${ }^{70}$ Significant to note in this regard is the practice of so-called 'pods', which entail (mostly hidden) collaborations on social media between a group of digital influencers. Members of a pod agree to like and comment on each other's videos in a specific manner (e.g. using a minimum amount of words, using enough hashtags), with the aim of being prioritised by the algorithm of the platform and appear more often in

68 European Commission, 'Commission Staff Working Document: Guidance on the Implementation/Application of Directive 2005/29/Ec on Unfair Commercial Practices' (2009) <http://ec.europa.eu/justice/consumer-marketing/files/ucp_guidance_2009_en.pdf> accessed 16 January 2018.

${ }^{69}$ European Commission (n 64).

${ }^{70}$ European Commission (n 64). 
consumers' search results or newsfeeds. ${ }^{71}$ Considering that these collaborations are largely unknown to the public, it may constitute a misleading commercial practice. Therefore, it is argued that digital influencers participating in pods should disclose this to their consumer-followers.

Finally, as mentioned, digital influencers are particularly popular amongst children and adolescents. Accordingly, article 5(3) of the UCP Directive could provide a legal basis of protecting "a clearly identifiable group of consumers who are particularly vulnerable". The EC explains that this legal basis reinforces the general identification requirements (i.e. clearly indicating the marketing purpose). ${ }^{72}$ Furthermore, digital influencers need to keep in mind that their vlogs cannot contain a direct exhortation to children to buy a certain product or persuade their parents or other adults to buy such a product for them. For instance, statements of vloggers such as "Go buy the book now" or "Tell your mom to get it from the local store" would be prohibited under the UCP Directive. This does not imply an outright ban on advertising, but merely aims at providing protection to children against direct exhortations to purchase. ${ }^{73}$

\subsubsection{Unfair commercial practices by the video-sharing platform}

The VSP provider can also qualify as a trader under the UCP Directive. In its 2016 guidance document on the application of the UCP Directive, the European Commission explains that it must be assessed on a case-by-case basis whether a platform service provider is acting as a trader, whether it is engaging in a commercial practice and whether this practice is aimed towards consumers. ${ }^{74}$ In particular, the Commission stresses that platform service providers may be acting as traders when they draw revenues from targeted advertising. ${ }^{75}$ In addition, the VSP provider may put in place commercial practices such as facilitating and selling paid 'likes' and sponsored reviews, blogs and accounts to third-party traders. Conversely, for third-party advertising, the VSP provider will not have direct obligations under the UCP Directive. ${ }^{76}$ The VSP provider also needs to inform users about any processing of their personal data for commercial purposes, otherwise this could be

\footnotetext{
${ }^{71}$ For instance, regarding pictures or vlogs on Instagram, the more likes and comments a post receives shortly after posting, the better it will perform in the algorithm. High initial engagement signals to Instagram that quality, engaging content is posted and as a result, the post can move higher up in people's feeds (and potentially go viral through the Instagram Explore page). G. Barkho, 'Inside Instagram Pods: The Secret Trick to Increase Your Engagement' (Later Blog, 23 February 2017) <https://later.com/blog/instagram-pods/> accessed 18 January 2018.

72 European Commission (n 64).

73 M. Capello, 'Article 13 TWFD' in O. Castendyk, E. Dommering and A. Scheuer (eds), European Media Law (Kluwer Law International 2008).

${ }^{74}$ European Commission (n 64).

${ }^{75}$ European Commission (n 64) 122. Also supported by the CJEU in the Papasavvas case: Sotiris Papasavvas v $O$ Fileleftheros Dimosia Etaireia Ltd and Others [2014] CJEU C-291/13.

76 For instance with regard to advertorials, the CJEU held that the prohibition was applicable to the trader whose products or services were advertised, rather than for instance the provider of a newspaper via which the advertisement is published. In other words, the Court found that there was no direct obligation on the newspaper in EU law. CJEU RLvS Verlagsgesellschaft v Stuttgarter Wochesblatt. RLvS Verlagsgesellschaft mbH v Stuttgarter Wochenblatt GmbH [2013] CJEU C-391/12; G. Howells, C. Twigg-Flesner and T. Wilhelmsson, Rethinking EU Consumer Law (Routledge 2017).
} 
considered an omission of material information necessary for informed commercial decision-making. Article 7 of the UCP Directive prohibits such an omission if it is shown that it is likely to cause the average consumer to take a transactional decision he would not have taken otherwise. ${ }^{77}$

\subsection{Further guidance for vloggers in self-regulation: the curious chain of events in Belgium}

From the analysis provided above, it can be concluded that the general identification requirement is applicable to digital influencers. However, the implementation thereof in practice is not specified in the current EU legislative framework. The same requirement can also be found in self-regulation, for instance in the International Chambers of Commerce Code of Advertising and Marketing Communication Practice (ICC Code) ${ }^{78}$, but again, without practical guidance on how to disclose commercial relationships in practice. Recently, however, several national self-regulatory authorities, as well as groups of digital influencers themselves, have issued or pledged to follow guidelines on how to disclose commercial relationships in online videos. ${ }^{79}$ More specifically in Belgium, a remarkable chain of events took place, which caught the attention of the media and the general public. $^{80}$

First, on May 15th 2018 , the Belgian Federal Public Service Economy (FPS Economy) provided a set of guidelines for influencer marketing on social media. The guidelines dedicated a seperate subsection to vloggers, who were required to add a disclosure to their videos (i.e. the word 'reclame' in writing) whenever commercial statements were made. The disclosure should be shown at regular intervals of at least every fifteen seconds and should be visible for at least three seconds each time. The disclosure could not be hidden between hashtags or at the end of the video. The company or brand behind the advertisement should also be identified. However, immediately after their release, the FPS Economy withdrew the guidelines, as they had been published before being validated. ${ }^{81}$

\footnotetext{
${ }^{77}$ Again, article 5 (3) UCP Directive could present a legal basis for the protection of children in this regard, and as such, reinforces the information requirement and lowers the threshold when it comes to defining whether or not the omission has influences the consumer's transactional decision-making (i.e. the average consumer will be a child).

78 International Chamber of Commerce, 'Consolidated Code of Advertising and Marketing Practice' $<$ https://cdn.iccwbo.org/content/uploads/sites/3/2011/08/ICC-Consolidated-Code-of-Advertising-andMarketing-2011-English.pdf> accessed 14 November 2017.

${ }^{79}$ For instance in the UK: Committee of Advertising Practice guidelines for vlogging advertising, available at <https://www.asa.org.uk/advice-online/video-blogs-scenarios.html\#.WGZ9DTNF270> accessed 30 October 2018; and in the Netherlands: Social Code Youtube, available at <https://www.cvdm.nl/wpcontent/uploads/2017/11/Social_Code_YouTube.pdf> accessed 30 October 2018.

80 D. Deckmyn, 'ONWETTIGE VERKOOPSPRAKTIJKEN ZIJN VASTE PRIK OP YOUTUBE. De Vlaamse Youtuber Acid roept zijn minderjarige fans op om zijn truien te kopen, en daarvoor de creditcard van hun ouders te stelen. Een overtreding van de wet, maar niemand kijkt erop toe.', De Standaard, 21 September 2018, <http://www.standaard.be/cnt/dmf20180920_03770634> accessed 30 October 2018.

81 X., 'Voorlopig toch geen strengere regels voor influencers' (De Standaard) <http://www.standaard.be/cnt/dmf20180515_03513682> accessed 2 August 2018.
} 
Interesting to note is that the guidelines would have been legally enforceable and that non-compliance could lead to fines.

A second event concerns a decision by the Jury for Ethical Practices in Advertising ("JEP") about questionable statements made by a digital influencer, in and accompanying one of his vlogs. ${ }^{82}$ The initial complaint ${ }^{83}$ leading to the decision was submitted before the FPS Economy ${ }^{84}$, but was in the end handled by the JEP. ${ }^{85}$ In its decision, the JEP requested the influencer involved to either change or remove the contested vlog, based on the national implementation ${ }^{86}$ of the UCP Directive and the self-regulatory ICC Code. However, up until the time of writing, the vlogger involved did not change or delete the contested video, but on the contrary, made a video ridiculing the decision. Although the decision in itself is laudable, it misses impact in practice due to the JEP's lack of real enforcement powers.

Following this decision, the JEP has published its own guidelines on commercial practices by digital influencers. ${ }^{87}$ These guidelines aim to assist digital influencers, advertising companies, agencies, media and platforms with regard to consumer protection and legal certainty. The document is built upon the principles of identification, fairness and transparency, which have been formed into four concrete guidelines. First, online influencers have to disclose any commercial relationship with a brand in a visual or audible way. ${ }^{88}$ This should guarantee transparent communication. Second, the words or hashtags disclosing the commercial intent of the vlog will need to be adjusted in function of the language of the message or target audience, as social media does not have (linguistic) boundaries (publicité, advertising, promoted, ad, paid, ...). Third, the disclosing words should be mentioned in such a way and place that the recipient immediately understands the correct nature of the message. Finally, the words should not be hidden:

\footnotetext{
${ }^{82}$ In the contested video, the vlogger addresses his young audience while elaboratly praising a sweater that is for sale on his website. A number of questionable statements are used in and around the video. For example, the title of the vlog reads: 'GRATIS ECHTE BROER TRUIEN' (freely translated: 'free sweaters for real fans'). While watching the video, however, it becomes clear that the sweaters in fact cost €30. Besides this, the vlogger calls upon his (mostly underage) public to steal their parents' credit card in case they are not allowed to buy his merchandising. In addition, the vlogger also regularly emphasises that only when viewers buy one of his sweaters, they are considered to be 'real fans'.

83 This test case was submitted by the authors of this paper, after they discovered serious infringements by vloggers during their research.

${ }^{84}$ The FPS Economy responded saying it is not competent to deal with the complaint at hand, as its powers are situated within the framework of a number of well-defined economic regulations (of a criminal nature). It added that the JEP could be addressed because the issue in question concerns a commercial message, elements of which may be in conflict with the applicable legislation and/or self-disciplinary codes.

85 JEP decision, 'Acid Apparel', 12 September 2018, <https://www.jep.be/nl/nieuws/acid-apparel-12-092018-beslissing-tot-wijzigingstopzetting> accessed 29 October 2018.

86 'Boek VI, Wetboek Economisch Recht'.

87 Aanbevelingen van de Raad voor de Reclame inzake online influencers, October 2018, <https://www.jep.be/sites/default/files/rule_reccommendation/aanbevelingen_van_de_raad_voor_de_re clame_online_influencers_nl.pdf> accessed 29 October 2018.

88 This has to be done by stating one of the following words : "reclame, advertentie, sponsoring, promotie, gesponsord door, in samenwerking met, ..." or hashtags: "\#spon, \#adv, \#prom, \#reclame, \#recl, \#sample, \#...".
} 
the average consumer will have to be able to take notice of the disclosure in normal circumstances.

Important to note is that the guidelines only apply to digital influencers if two conditions are fulfilled: (1) a remuneration was received, (2) the advertising company exercises control over the commercial communication. The latter envisages the situation where the advertiser and online influencers have agreed upon guidelines concerning the commercial message. This second condition raises some questions as it unreasonably limits the scope of the guidelines by excluding the situation where vloggers decide themselves on how to promote the product or service at hand. For example, cases where a vlogger would receive a product for free under the condition to make a video about that product, will not be covered by the guidelines unless the advertiser has explicitly ordered how the promotion of the product will have to take place. This is an important lacuna that limits the practical relevance of the guidelines.

\section{Conclusion}

From the analysis, it is clear that digital influencers need to identify commercial communications that are integrated in their videos. Although the regulatory framework currently requires that certain information needs to be made visible to the consumer, it leaves a wide berth for interpretation and implementation. At the national level, this has led to a number of self-regulatory initiatives, providing guidelines for the labelling of vlogging advertising (e.g. the UK, the Netherlands, Belgium). These self-regulatory instruments contain specific instructions for the implementation of the legal identification requirement in the context of vlogging, making it easier for digital influencers to comply. However, regarding the guidelines provided in Belgium, it was concluded that their scope of application was limited in practice. In addition, the lack of a coordinated approach at the EU level and the resulting distributed nature of labelling requirements could raise practical questions regarding enforcement. Furthermore, as digital influencers are highly popular amongst children, it could be questioned whether the labelling guidelines and current industry practices were developed with a children's audience in mind. Accordingly, it is argued that a coordinated, evidence-based approach to labelling, also taking into account the specific needs of children, could be useful for the proper implementation of the identification principle. The European Advertising Standards Alliance could take up a coordinating role in this regard.

Aside from digital influencers, VSP providers also have important responsibilities for commercial communications distributed via their platforms. The legal framework distinguishes between those advertisements that are marketed, sold or arranged by the platform and third-party advertisements. With regard to the first category, both the AVMS and the UCP Directive require VSP providers to identify them as commercial communications. Furthermore, the VSP provider has a number of other responsibilities concerning the protection of minors specifically (e.g. protect them against harmful advertising content) and the public in general (i.e. protect them against hate speech, 
illegal content). The VSP provider must also refrain from unfair commercial practices such as facilitating and selling paid 'likes' and sponsored reviews, blogs and accounts to thirdparty traders. With regard to the second category, both the AVMS and UCP Directives recognise that VSP providers have limited control over content and commercial communications uploaded by third parties. Accordingly, rather than having a general obligation to monitor or filter uploaded content for harmful commercial communications, the revised AVMS Directive requires platform providers to foresee appropriate measures to ensure the protection of minors and the general public (e.g. flagging mechanisms, age verification mechanisms, parental control systems). The European Commission is also encouraged by the revised AVMS Directive to develop co-regulatory mechanisms for appropriate measures. In this regard, it is argued that the EC should ensure that they take into account social science studies and that these co-regulatory mechanisms are evaluated and updated on a regular basis.

Finally, the analysis showed that certain provisions of the UCP Directive could form an important layer of protection for consumer-followers against certain types of 'unfair' vlogging advertising practices. Due to its broad scope of application, the Directive can also cover new commercial practices such as fake likes, hidden traders, instagram pods or any other persuasive tactic emerging in the future. 


\section{Bibliography}

\section{Legislation and policy}

Directive 2000/31/EC of the European Parliament and of the Council of 8 June 2000 on certain legal aspects of information society services, in particular electronic commerce, in the Internal Market (Directive on electronic commerce)

Directive 2005/29/EC of the European Parliament and the Council of 11 May 2005 concerning unfair business-to-consumer commercial practices in the internal market and amending Council Directive 84/450/EEC, Directives 97/7/EC, 98/27/EC and 2002/65 /EC of the European Parliament and of the Council and Regulation (EC) No 2006/2004 of the European Parliament and of the Council ('Unfair Commercial Practices Directive')

Directive 2010/13/EU of the European Parliament and of the Council of 10 March 2010 on the coordination of certain provisions laid down by law, regulation or administrative action in Member States concerning the provision of audiovisual media services (Audiovisual Media Services Directive)

European Commission, 'Commission Staff Working Document: Guidance on the Implementation/Application of Directive 2005/29/Ec on Unfair Commercial Practices' (2009) $<$ http://ec.europa.eu/justice/consumermarketing/files/ucp_guidance_2009_en.pdf> accessed 16 January 2018

- - 'Commission Staff Working Document - Guidance on the Implementation/Application of Directive 2005/29/EC on Unfair Commercial Practices, SWD(2016) $163 \quad$ Final.' (2016) <http://ec.europa.eu/justice/consumermarketing/files/ucp_guidance_en.pdf> accessed 9 October 2017

\section{Case law and self-regulatory decisions}

Barthold v Germany [1985] ECtHR App No 8734/79

Casado Coca v Spain [1994] ECtHR Series A., No. 285

Peugeot Deutschland GmbH v Deutsche Umwelthilfe eV [2018] CJEU C-132/17

RLvS Verlagsgesellschaft mbH v Stuttgarter Wochenblatt GmbH [2013] CJEU C-391/12

Sotiris Papasavvas v O Fileleftheros Dimosia Etaireia Ltd and Others [2014] CJEU C-291/13

JEP, Acid Apparel, 12 September 2018.

\section{Documents by (alternative) regulatory bodies}

International Chamber of Commerce, 'Consolidated Code of Advertising and Marketing Practice' < <https://cdn.iccwbo.org/content/uploads/sites/3/2011/08/ICCConsolidated-Code-of-Advertising-and-Marketing-2011-English.pdf> accessed 14 November 2017 
Ofcom, 'Children's Content Review : Update Assessing the Current Provision of Children's Programmes on TV and Online' (2018) <https://www.ofcom.org.uk/_data/assets/pdf_file/0023/116519/childrens-contentreview-update.pdf $>$ accessed 2 August 2018

\section{Journal articles, books, book chapters, research reports}

'Acumen Report: Youth Video Diet' (Defy Media) <http://defymedia.com/wpcontent/uploads/2017/11/Acumen_DL_booklet_16_12_04.pdf> accessed 29 November 2017

Bandura A and Walters RH, Social Learning and Personality Development (Holt, Rinehart and Winston 1963)

Barkho G, 'Inside Instagram Pods: The Secret Trick to Increase Your Engagement' (Later Blog, 23 February 2017) <https://later.com/blog/instagram-pods/> accessed 18 January 2018

Bentley AR, Earls M and O'brien M J, I'll Have What She's Having - Mapping Social Behavior <https://mitpress.mit.edu/books/ill-have-what-shes-having> accessed 29 November 2017

Berg M, 'The Highest-Paid YouTube Stars 2016: PewDiePie Remains No. 1 With \$15 Million' (Forbes) <https://www.forbes.com/sites/maddieberg/2016/12/05/thehighest-paid-youtube-stars-2016-pewdiepie-remains-no-1-with-15-million/> accessed 15 December 2017

Capello M, 'Article 13 TWFD' in Olivier Castendyk, Egbert Dommering and Alexander Scheuer (eds), European Media Law (Kluwer Law International 2008)

Chavannes R and Castendyk 0, 'Directive 2007/65/EC “Audiovisual Media Services Directive"' in Oliver Castendyk, Egbert Dommering and Alexander Scheuer (eds), European Media Law (Kluwer Law International 2008)

Clifford D and Verdoodt V, 'Integrative Advertising: The Marketing'dark Side'or Merely the Emperor's New Clothes?' (2017) 8 European Journal of Law and Technology <http://ejlt.org/article/view/547> accessed 8 August 2017

Closs W, Nikoltchev S and European Audiovisual Observatory (eds), The Regulation of OnDemand Audiovisual Services: Chaos or Coherence? (European Audiovisual Observatory: Council of Europe 2011)

Costine J, 'Facebook Launches Watch Tab of Original Video Shows' (Techcrunch, 9 August 2017) <https://techcrunch.com/2017/08/09/facebook-watch/> accessed 15 December 2017

Covington P, Adams J and Sargin E, 'Deep Neural Networks for YouTube Recommendations' (ACM Press 2016) <http://dl.acm.org/citation.cfm?doid=2959100.2959190> accessed 7 December 2017 
DG CONNECT, 'REFIT Evaluation and Impact Assessment of the EU Audiovisual Media Services Directive 2010/13/EU (AVMSD)' <http://ec.europa.eu/smartregulation/roadmaps/docs/2015_cnect_006_cwp_review_avmsd_iia_en.pdf > accessed 6 December 2017

Dheur J, 'Belgian CSA Conference - The Platform Is the Message' (2016) <http://www.csa.be/system/documents_files/2591/original/CI_20160310_The\%20Pla tform\%20is\%20the\%20Message_report.pdf?1458160565> accessed 11 December 2017

Ehle K, 'Digital Single Market Update: The European Commission's Proposal to Revise the Audiovisual Media Services Directive' (Lexology) <https://www.lexology.com/library/detail.aspx?g=dc9d66d9-f916-4f0b-b0cc-

f3b6e2f45de4> accessed 15 December 2017

Gruen TW, Osmonbekov T and Czaplewski AJ, 'EWOM: The Impact of Customer-toCustomer Online Know-How Exchange on Customer Value and Loyalty' (2006) 59 Journal of Business Research 449

Hellemans L, Lievens E and Valcke P, 'Playing Hide-and-Seek? A Legal Perspective on the Complex Distinction between Commercial and Editorial Content in Hybrid Advertising Formats' (2015) 17 info 19

Hermanns O, Matzneller P and Nikoltchev S, 'The Regulation of On-Demand Audiovisual Services: Chaos or Coherence?' [2011] IRIS Special: The regulation of on-demand audiovisual services : chaos or coherence?

Howells G, Twigg-Flesner C and Wilhelmsson T, Rethinking EU Consumer Law (Routledge 2017)

Jackson J, 'Children Spending Less Time in Front of the TV as They Turn to Online Media' The Guardian (6 August 2015) <http://www.theguardian.com/media/2015/aug/06/children-spending-less-time-infront-of-tv-ofcom> accessed 7 December 2017

Lambrecht I, Verdoodt V and Bellon J, 'Platforms and Commercial Communications Aimed at Children: A Playground under Legislative Reform?' [2018] International Review of Law, Computers and Technology

Lee JE and Watkins B, 'YouTube Vloggers' Influence on Consumer Luxury Brand Perceptions and Intentions' (2016) 69 Journal of Business Research 5753

Miller NE and Dollard J, Social Learning and Imitation (Yale University Press 1941)

Perse EM and Rubin RB, 'Attribution in Social and Parasocial Relationships' (1989) 16 Communication Research 59

Schoefs R, 'Connected TV: Editorial Responsibility in a Converged Media Environment' (2014) 5 Droit des médias - Mediarecht 346 
Stokel-Walker C, 'Vloggers Unite: Youtubers Are Getting Organized after a Decade of Exploitation' Newsweek (8 October 2016) <http://www.newsweek.com/vloggersyoutube-organized-decade-exploitation-507592> accessed 11 December 2017

Trusov M, Bucklin RE and Pauwels K, 'Effects of Word-of-Mouth versus Traditional Marketing: Findings from an Internet Social Networking Site' (2009) 73 Journal of marketing 90

Valcke P and Lievens E, 'Rethinking European Broadcasting Regulation: Unraveling Europe's Policy for the Digital Media Landscape: Critical Analysis of the Audiovisual Media Services Directive' (VUB Press 2009)

Vanwesenbeeck I and others, 'Minors' Advertising Literacy in Relation to New Advertising Formats - Identification and Assessment of the Risks' (2016) <www.adlit.be> accessed 16 November 2017

Verdoodt V, 'Children's Rights and Advertising Literacy in the Digital Era: Towards an Empowering Regulatory Framework for Commercial Communication' (KU Leuven, UGent 2018)

Verdoodt V, Lambrecht I and Lievens E, 'Mapping and Analysis of the Current Self- and CoRegulatory Framework on Commercial Communication Aimed at Minors. A Report in the Framework of the AdLit SBO Project.' <www.adlit.be> accessed 20 November 2017

Verdoodt V, Lievens E and Hellemans L, 'Mapping and Analysis of the Current Legal Framework on Commercial Communication Aimed at Minors. A Report in the Framework of the AdLit Research Project.' (2015) <www.adlit.be> accessed 20 November 2017

'Voorlopig toch geen strengere regels voor influencers' (De Standaard) <http://www.standaard.be/cnt/dmf20180515_03513682> accessed 2 August 2018

Ward J, ‘CAP Guidance on Vlogging Advertising’ [2016] Entertainment Law 49 